\title{
An ecological study of Electra posidoniae Gautier, 1954 (Cheilostomata, Anasca), a bryozoan epiphyte found solely on the seagrass Posidonia oceanica (L.) Delile, 1813
}

\author{
Gilles Lepoint ${ }^{1}$, Olivier Mouchette ${ }^{1}$, Corine Pelaprat ${ }^{2} \&$ Sylvie Gobert ${ }^{1}$
}

1 Oceanology, Centre MARE, University of Liège, Belgique

2 STARESO (STAtion de REcherches Sous-marines et Océanographiques), Calvi, Corse, France

\begin{abstract}
The bryozoan Electra posidoniae Gautier is found solely on the leaves of the Neptune grass Posidonia oceanica (L.) Delile, dominating the leaf epifauna of this seagrass. Epiphytes of marine angiosperms (or seagrasses) often play an important role in ecosystem functioning, for example as food web suppliers. As dysfunction of the epiphytic component is often implied in human-induced seagrass decline, it is important to understand the dynamics and life traits of this community in pristine areas. This study involved the monthly assessment of colonization dynamics, biomass seasonality, and diet composition through measurements of stable isotopes, in E. posidoniae at a depth of $10 \mathrm{~m}$ in the Revellata Bay (Corsica, Mediterranean Sea). Ancestrulae (i.e. colony founders) appeared towards the end of winter and were very selective in their settlement position along the leaves of $P$. oceanica. A maximum of 100,000 colonies per square meter was recorded. Colonies of E. posidoniae dominated the epiphytic community biomass in early spring, but were overtaken by epiphytic algae in June. Food shortage could be involved in this reduction in dominance. Although stable isotope ratios of $\mathrm{C}, \mathrm{N}$ and $\mathrm{S}$ showed that this suspension feeder mainly relies on the water column for its food, other food sources such as re-suspended epiphytic diatoms could be important in late spring (i.e. after the phytoplanktonic bloom). Additionally, a contribution of seagrass phytodetritus to the diet of this species cannot be excluded. The species was almost absent in winter, raising the question of its recruitment in spring. This study confirms the quantitative importance of this species in the seagrass meadow and explores its role in the relationship between the water column and this seagrass ecosystem.
\end{abstract}

KEY WORDS: biofouling, bryozoan, seagrass, stable isotopes, Neptune grass, NW Mediterranean

\section{INTRODUCTION}

The Neptune grass Posidonia oceanica (L.) Delile forms large submarine seagrass meadows in the coastal zone at a depth of up to $40 \mathrm{~m}$ and, in consequence of its large size and its relatively long life span, is fouled by many epiphytic species (PERES \& PICARD, 1964). This epiphytic community is a central component of the seagrass meadow ecosystem in terms of diversity (PERES \& PICARD, 1964; BOROWITZKA et al., 2006). Species living as epiphytes of marine angiosperms (or seagrasses) often play an important role in ecosystem functioning. They are important contributors to primary production (BOROWITZKA et al., 2006) and key components of the food web (LEPOINT et al., 2000; TOMAS et al., 2005; GACIA et al., 2009; VIZZINI, 2009; MiCHEL, 2011). They contribute to benthicpelagic coupling (LEMMENS et al., 1996) and to nitrogen and carbon cycling within the meadow (AlCOVERro et al., 2004; MATEO et al., 2006). Because epiphytic component dysfunction is often implied in human-induced seagrass decline (BALATA et al.2010), it is important to understand dynamics and life traits of this community.

Leaf epiphytic communities are typically dominated by photophilous brown macroalgae, red algae of the taxon Ceramiacae, and calcareous red algae (MAZZELLA et al., 1989). Nevertheless, some animal species, such as bryozoans, 
hydrozoans or sedentary polychaetes, are also found fixed on leaves of $P$. oceanica (PERES \& PICARD, 1964; HAYWARD, 1975; BOERO et al., 1985; LEPOINT et al., 1999). The most abundant and the most characteristic of these animals is Electra posidoniae Gautier 1954 (Fig. 1), an anascan bryozoan specialized in epiphytic colonisation and strictly restricted to the leaves of P. oceanica (GAUTIER, 1961). This species is frequently found almost entirely covering the internal faces of leaves (DALLA VIA et al., 1998). It is recognised as a true species differing both morphologically and genetically from the "cosmopolitan" Electra pilosa species complex (NiKULINA et al., 2007). E. posidoniae displays life history traits that could be considered as hyperadapted to epiphytism on leaves of Posidonia. For example, the settlement of ancestrulae (i.e. colony founders) is highly selective in terms of substrate choice (never found on any substrate besides Neptune grass leaves), of leaf face choice (generally the inner side), of place on the leaf face (generally in the middle of the leaf width), and in term of orientation (generally aligned to allow colony growth towards the leaf apex) (MATRICARDI et al., 1991; DALLA VIA et al., 1998). Moreover, colonies are constituted of zooids with multiserial encrusting morphology (MCKINNEY \& JACKSON, 1989); this morphology is particularly efficient in the colonisation of

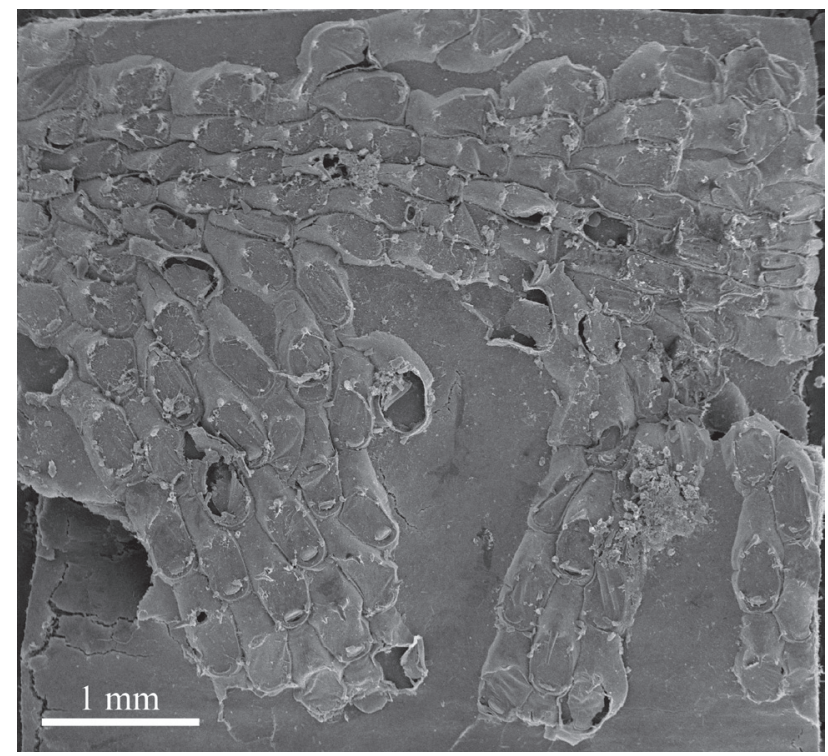

newly-formed leaves. Colonies tend to grow parallel to the leaf veins and are flexible because they are lightly calcified (GAUTIER, 1961). This morphology is adapted to substrate deformation (i.e. leaf flexibility), reducing the risk of colony breaking. Finally, zooids are large compared to other epiphytic bryozoans and rapidly colonize the available substrate; this is probably a competitive advantage over other epiphytic taxa (LEPOINT et al., 2014).

Electra posidoniae is a common suspension feeder in the Mediterranean sublittoral benthos, probably contributing to the energetic and material coupling between the water column and the benthic compartment, in a similar way to other suspension feeders in other seagrass meadows (LEMMENS et al. 1996). However, in the oligotrophic Mediterranean, microphytoplankton (i.e. diatoms) is a very seasonal resource, restricted primarily to the beginning of spring. In late spring and summer, smaller phytoplanktonic species dominate and are not necessary available or suitable for bryozoan feeding. For this reason food shortage is often observed in some Mediterranean suspensivores (COMA \& RIBES 2003). Alternative food sources could exist for E. posidoniae, for example microepiphytes (bacteria, protists or diatoms), (NOVAK, 1984; MABROUK et al., 2011), which could constitute a

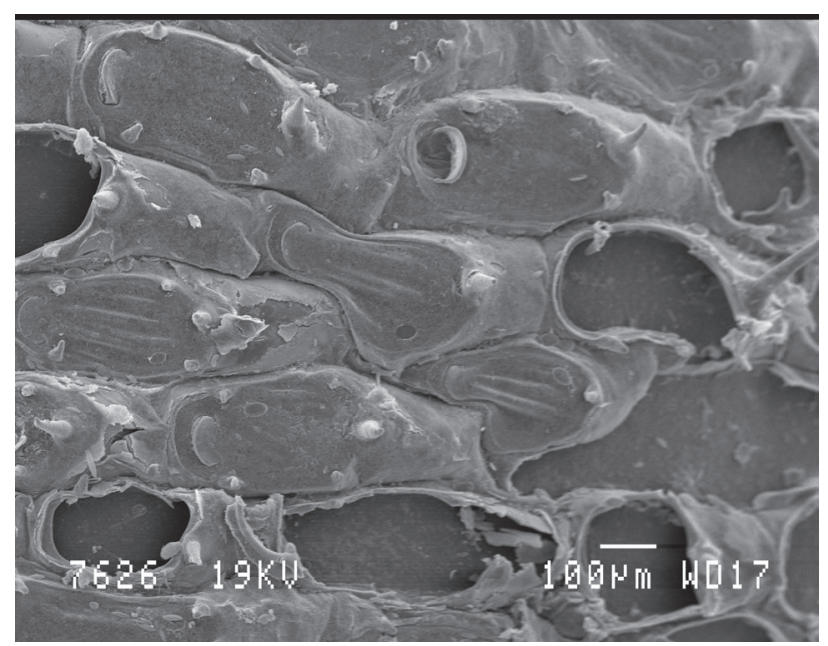

Fig. 1. - SEM microphotographs of a colony of Electra posidoniae on a leaf of Posidonia oceanica (a) with a more detailed view of some zooids (b). Photography: F. REMY. 
food source when detached from their substrate. Moreover, seagrass meadows are known to produce large amounts of phytodetritus, which fuels detritic food webs (CEBRIAN \& LARTIGUE, 2004). This detritus may sometimes form a large part of the suspended particulate organic matter (SPOM), depending on hydrodynamic conditions (DAUBY et al., 1995).

To the best of our knowledge, the seasonal population dynamics of E. posidoniae have not previously been quantitatively assessed. Therefore, our first aim in this study was to assess these dynamics at monthly intervals in terms of biomass, leaf covering and colony numbers. Assessments were made over a period of one year at a $10 \mathrm{~m}$ depth. Secondly, stable isotope analyses were conducted to estimate the contribution of alternative food sources (i.e. Posidonia detritus, detached microepiphytes) to the diet of E. posidoniae. Thirdly, we have attempted to quantify the potential role of $E$. posidoniae in the benthic-pelagic coupling.

\section{MATERIAL AND METHODS}

\section{Sampling}

Within a permanent quadrate $(3 \times 3 \mathrm{~m})$, five shoots of $P$. oceanica were harvested at monthly intervals in the Revellata Bay (Calvi Bay, NW Corsica) near the oceanographic station STARESO (University of Liège) at a depth of 10 m. Samples were taken between November 2002 and November 2003. Shoots were immediately frozen at $-18^{\circ} \mathrm{C}$ until analysis.

Shoot density, measured at monthly intervals using a circle with a diameter of $40 \mathrm{~cm}$ randomly set in the meadow ( $\mathrm{n}=10$ counts /campaign), was $452 \pm 127$ shoots. $\mathrm{m}^{-2}$.

\section{Sample processing}

Shoots were dissected to separate the leaves, and the length and width of each leaf were recorded to calculate the surface area of one leaf side. Total leaf surface per shoot was calculated as the sum of each leaf surface multiplied by two to account for each leaf side.

Each month, for each shoot, the numbers of colonies and ancestrulae (i.e. the colony founder) of $E$. posidoniae were recorded, and assigned to a leaf face (internal or external).

Colonies were collected with a razor blade, oven-dried at $50^{\circ} \mathrm{C}$ and weighed to obtain the total dry mass per shoot (mgDM.shoot $\left.{ }^{-1}\right)$. The remaining epiphytes were scraped off with a razor blade. Cleaned leaves and remaining epiphytes were also oven-dried and weighed.

To estimate cover of E. posidoniae $\left(\mathrm{cm}^{2}\right.$ colony ${ }^{\circ}$ shoot $\left.^{-1}\right)$, the relationship between the colony mass (mgDM.shoot $\left.{ }^{-1}\right)$ and the colony surface $\left(\mathrm{cm}_{\text {colony }}^{2}\right)$ was established. Twenty $\mathrm{cm}^{2}$ of $E$. posidoniae were scraped from a pool of shoots sampled in April 2005 and average grammage $\left(\mathrm{gDM} . \mathrm{cm}^{-2}\right.$ colony $)$ was determined after drying at $60^{\circ} \mathrm{C}$ during 48 hours. This grammage was equal to $1.84 \mathrm{mgDM} . \mathrm{cm}^{-2}$ colony We have made the assumption that grammage was constant throughout the year.

\section{Stable Isotopes}

Colonies of E. posidoniae were ground using a mortar and pestle to obtain a homogeneous powder. Acidification can affect the isotopic ratio of nitrogen and of sulphur, so for this reason $\mathrm{N}$ and $\mathrm{S}$ stable isotope compositions were determined prior to acidification (PINNEGAR \& Polunin, 1999; CONNOLly \& SCHLACHER, 2013). However, because colonies are lightly calcified and because the carbon stable isotope ratios of carbonate do not reflect the animal diet, samples for determining $\mathrm{C}$ stable isotope compositions were acidified in a closed glass receptacle using vapours of fuming $\mathrm{HCl}(37 \%$, P.A., Merck). Measurements were conducted using an Isoprime 100 mass spectrometer (Isoprime, United Kingdom) coupled to a Vario 
Microcube elemental analyser (Elementar, Germany). Stable isotope ratios were expressed in $\delta$ notation (in \%o) according to the following:

$$
\delta X=\frac{\left(\mathrm{R}_{\text {sample }}-\mathrm{R}_{\text {standard }}\right)}{\mathrm{R}_{\text {standard }}} \times 1000
$$

where $X$ is ${ }^{13} \mathrm{C}$ or ${ }^{15} \mathrm{~N}$ or and $R$ is the corresponding ratio ${ }^{13} \mathrm{C} /{ }^{12} \mathrm{C},{ }^{15} \mathrm{~N} /{ }^{14} \mathrm{~N}$ or ${ }^{34} \mathrm{~S} /{ }^{32} \mathrm{~S}$ for samples or standards. Carbon, nitrogen and sulphur isotopic ratios are expressed relative to the international standards vPDB (Vienna Peedee Belemnite), to atmospheric air, and to vCDT (Vienna Cañon Diablo Troilite), respectively. Certified reference materials were IAEA-N1 (ammonium sulphate) $\left(\delta^{15} \mathrm{~N}=+0.4 \pm 0.2 \%\right)$, IAEA C-6 (sucrose) $\left(\delta^{13} \mathrm{C}\right.$ $=-10.8 \pm 0.2 \%$ ) and IAEA S1 (silver sulphide) $\left(\delta^{34} \mathrm{~S}=-0.3 \%\right)$. Routine measurements were precise to within $0.2 \%$ for both $\delta^{13} \mathrm{C}$ and $\delta^{15} \mathrm{~N}$, and $0.3 \%$ for $\delta^{34} \mathrm{~S}$.

For potential food sources of E. posidoniae, we have taken data published relating to the Calvi Bay for carbon and nitrogen but have measured our own $\delta^{34} \mathrm{~S}$ for leaves of $P$. oceanica and suspended organic matter (SPOM).

\section{Calculation of filtration rates}

Based on literature data and our study, we have calculated the hourly filtered water volume and the associated potential daily amount of phytoplanktonic biomass filtered by our population of E. posidoniae according to following equations:

Filtered volume $=$ Filtration rate $\mathrm{x}$ E. posido-

Filtered volume $=$ Filtration rate $\mathrm{x}$ E. posidoniae biomass

Filtered biomass $=$ Plankton biomass $\mathrm{x}$ Filtered volume $\mathrm{x} \%$ Retention

Water volume filtered by E. posidoniae is expressed in $\mathrm{ml} \cdot \mathrm{h}^{-1} \cdot \mathrm{m}^{-2}$ seafloor, E. posidoniae biomass in $\mathrm{gDM} . \mathrm{m}^{-2}$ seafloor and filtration rate in $\mathrm{ml} \cdot \mathrm{h}^{-1} \cdot \mathrm{gDM}^{-1}$.
Filtration rates were measured using Electra bellula, an Australian epiphytic species of the seagrass Amphibolis spp. and macroalgae (LISBJERG \& PETERSEN, 2000). Biomass of filtered material is expressed in $\mu \mathrm{gN} \mathrm{m}{ }_{\text {seafloor }} \mathrm{d}^{-1}$ or $\mu \mathrm{gC} \mathrm{m}^{-2}$ seafloor $\mathrm{d}^{-1}$. Planktonic biomass nitrogen and carbon were measured in the Calvi Bay between 1997 and 1999 (LEPOINT et al., 2004) and averaged according to the following periods: "wintering" (January, December), blooming (February, March, April), post-blooming (May, July, August), fall (September- October). Retention efficiency was fixed to $25 \%$ (i.e. $25 \%$ of the particles passing though the filter are effectively retained by the filter), which is a minimum for this type of bryozoan (LISBJERG \& Petersen, 2000). We did not take into account any variability of this retention efficiency, for example in relation to particle size.

Because conditions concerning normality were met (D'Agostino \& Pearson omnibus normality test), isotopic data were analysed using a one-way ANOVA test with sampling dates as independent factors. Tukey's Multiple Comparison test was used to assess pairwise differences when ANOVA revealed statistically significant effects. All test results were considered as significant when $p$ was $\leq 0.05$. Statistical calculations were performed using GraphPad Prism 5 software.

\section{RESULTS}

Dry mass of leaves of $P$. oceanica showed a classical seasonal evolution, with minimal values during the winter (e.g. November 2002), maximum values during the summer (e.g. June) and a drastic decrease as a consequence of the autumnal leaf fall (Fig. 2). Total epiphytic dry mass also displayed seasonal trends, with maximal values reached in May (Fig. 2). Total epiphytic dry mass constituted between 1.13 $\pm 0.88 \%$ in November 2002 and $25.98 \pm 5.29$ $\%$ of the total aboveground biomass in April 2003. Dry mass of E. posidoniae was very low in winter samples, increased in early spring, reached a maximal point in April and decreased 
drastically between June and July (i.e. before leaf abscission) (Fig. 2). The remaining epiphytic biomass, which was mainly represented by epiphytic algae, was also minimal in winter samples, increased slightly later than that of $E$. posidoniae, was maximal in July and drastically decreased between July and September (Fig. 2). E. posidoniae represented between $0.5 \pm 0.3 \%$ of the total epiphytic dry mass in November 2002 and $47.2 \pm 5.3 \%$ in March 2003, which corresponded respectively to 0.01 and $10 \%$ of the total aboveground dry mass.

The total number of colonies per shoot was minimal in winter and maximal in spring (i.e. March to May) samples, varying between 0 and 229 colonies per shoot (Fig. 3). If this number is expressed in terms of the shoot density at $10 \mathrm{~m}$ depth, this represented between 0 and 103,000 colonies of E. posidoniae per $\mathrm{m}^{2}$ seafloor

The total number of ancestrulae was very low (Fig. 3). They were almost absent from September to December, showed low abundance in January and February, peaked in March and decreased drastically in June.
Ancestrulae were mainly (60 to $100 \%$ ) found on the internal face (i.e. the concave face). This positioning was conserved in developed colonies and averaged $80 \pm 20 \%$.

Using colony grammage (1.84 mgDM. $\mathrm{cm}^{-2}{ }_{\text {colony }}$ ) and colony dry mass (mgDM), we have calculated the average surface shoot area covered by $E$. posidoniae. This varied between 0 in December 2003 and $90 \mathrm{~cm}^{2}$ at the end of April 2004. Using these data and the surface of leaves calculated from our biometric data (i.e. leaf length and width), the proportion of leaf covered by $E$. posidoniae colonies was calculated (Fig. 4). It was minimal in December $(0.01 \%)$ and maximal in late April $(9.5 \pm 2.5 \%)$. It decreased from June till autumn, when it reached less than $2.5 \%$. The covered surface was mainly the inner leaf face.

The measured $\delta^{34} \mathrm{~S}$ values ranged from 13.9 to $18.2 \%$ (16.6 \pm 1.9 ; mean $\pm \mathrm{SD})$ for $\mathrm{SPOM}$ and from 14.2 to $18.8 \%$ o $(17.03 \pm 1.4$; mean \pm SD) for leaves of $P$. oceanica. These $\delta^{34} \mathrm{~S}$ values did not differ significantly between the two food sources. $\delta^{13} \mathrm{C}, \delta^{15} \mathrm{~N}, \delta^{34} \mathrm{~S}$ values of individual colonies of E. posidoniae ranged between -21.6 and $-17.3 \%$

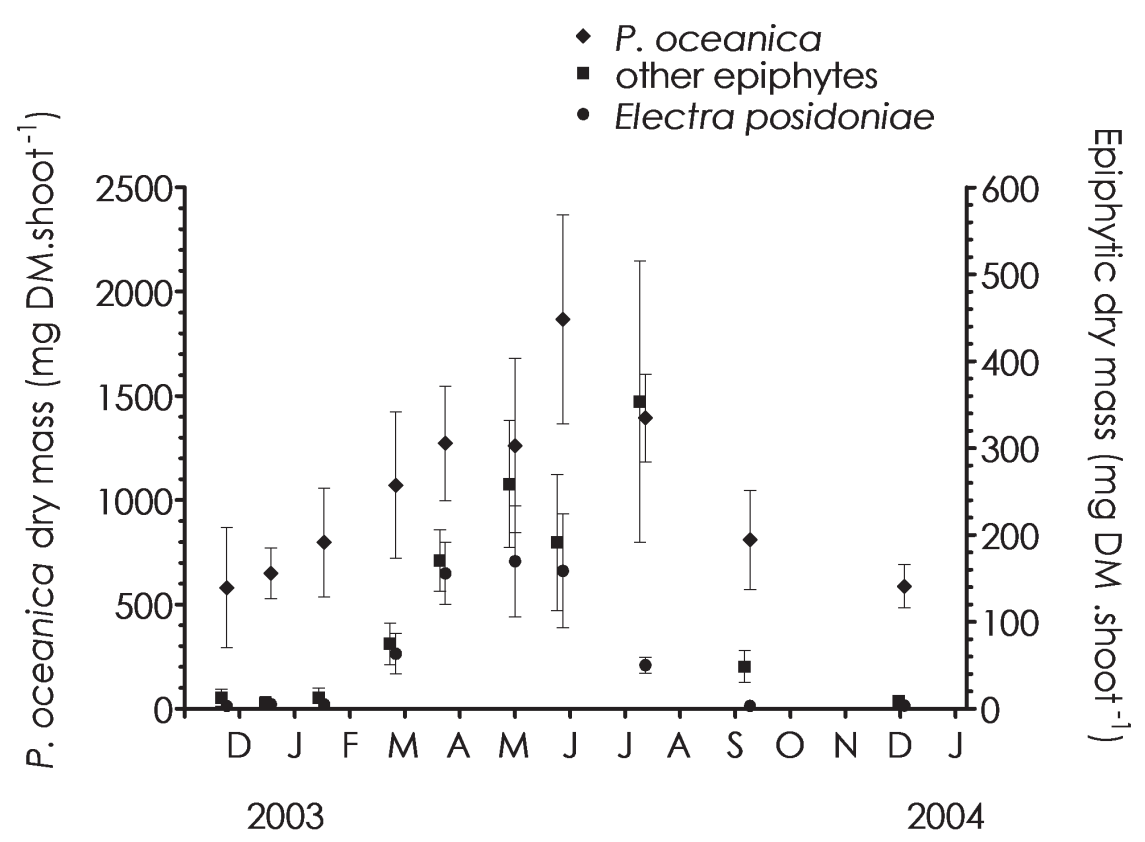

Fig. 2. - Dry mass (mean \pm S.D.) of leaves of Posidonia oceanica, of their epiphytic bryozoa Electra posidoniae, and of their other epiphytes, collected at a depth of $10 \mathrm{~m}$ in Revellata Bay between November 2003 and November 2004. 


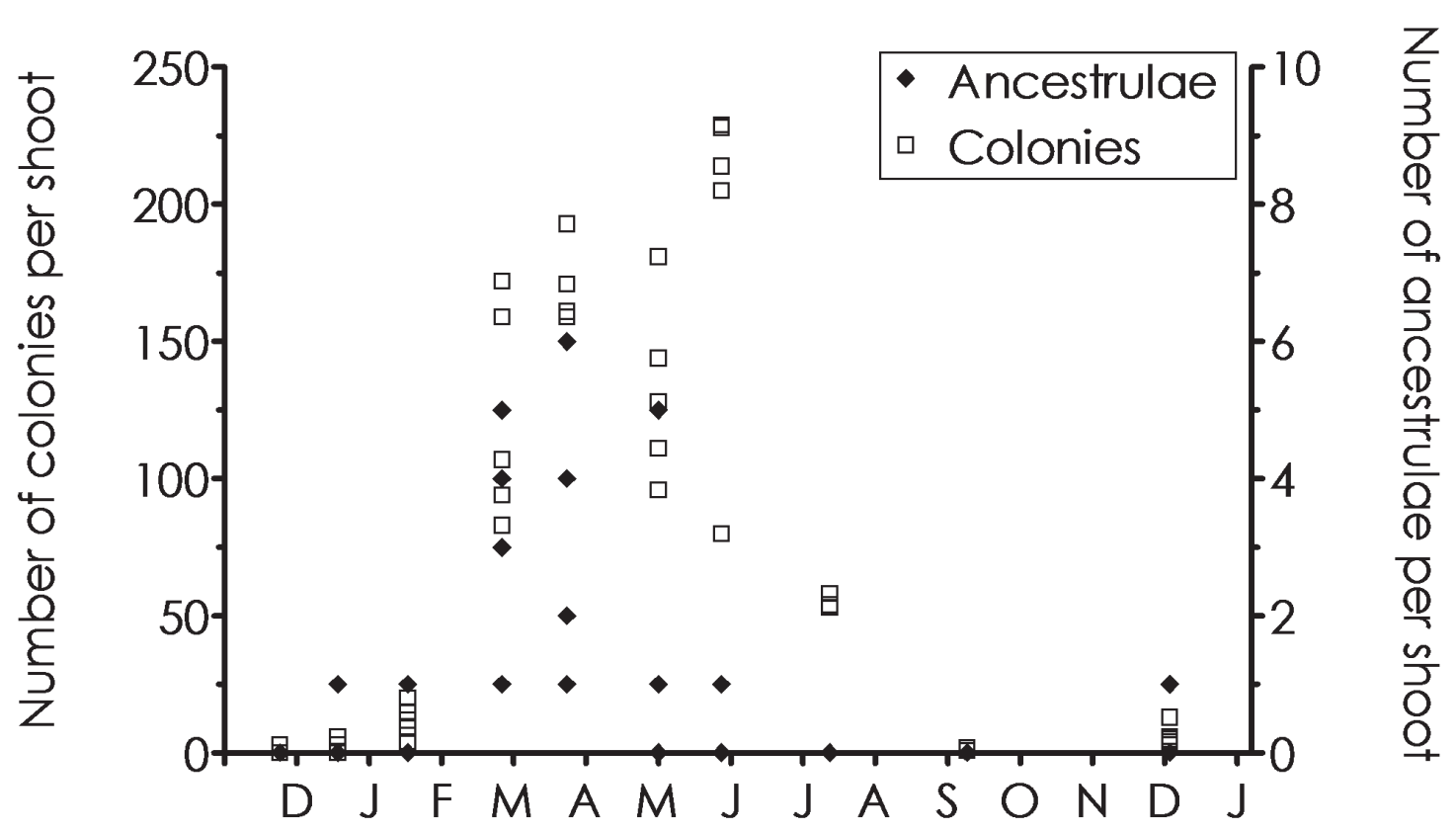

Fig. 3. - Total number of colonies of Electra posidoniae and of their ancestrulae, settled on leaves of Posidonia oceanica sampled at a depth of 10 m in Revellata Bay between November 2003 and November 2004.

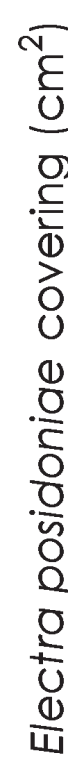
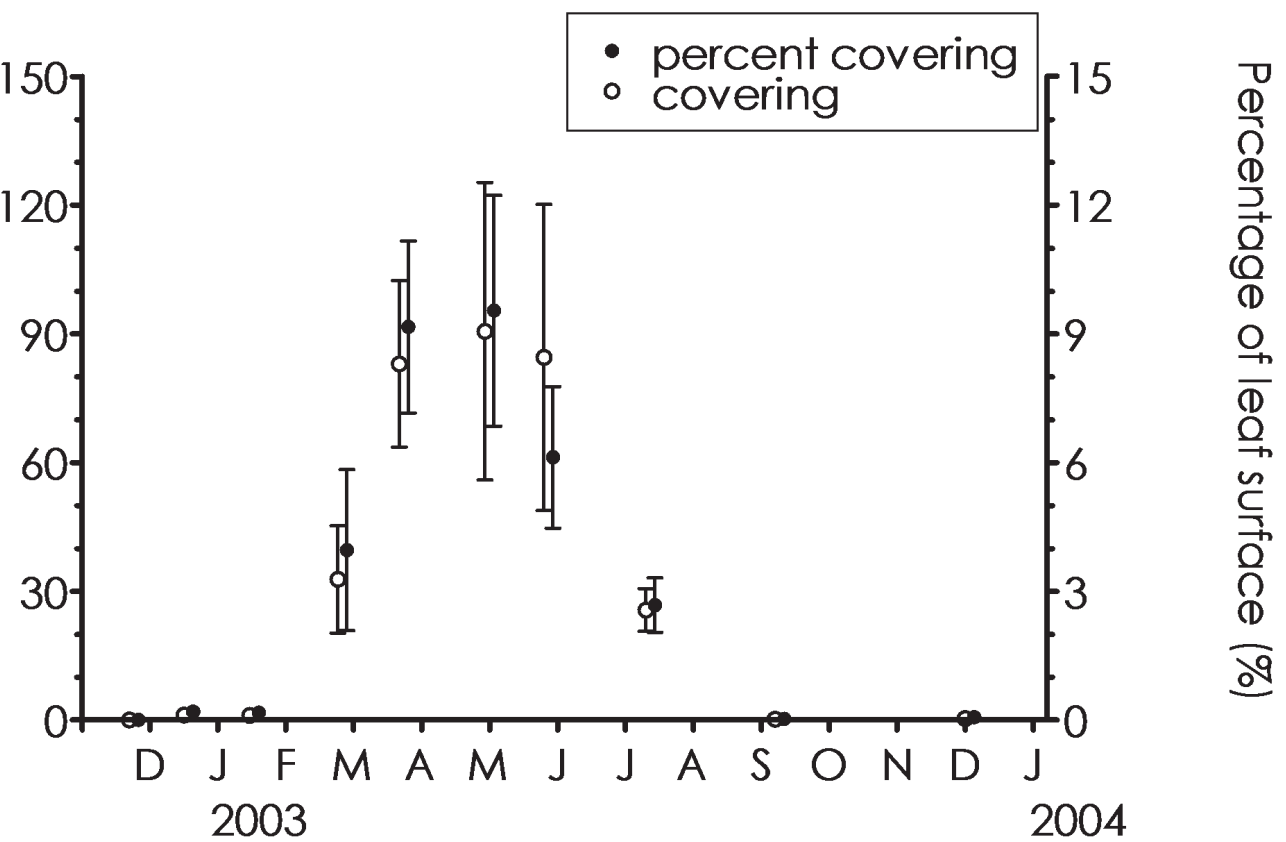

Fig. 4. - Averaged values ( \pm S.D.) of actual and percentage of leaf surface area of Posidonia oceanica covered by Electra posidoniae on leaves of $P$. oceanica sampled at a depth of $10 \mathrm{~m}$ in Revellata Bay between November 2003 and November 2004. 


\section{TABLE 1}

Summary of ANOVA results.

\begin{tabular}{|c|c|c|c|c|c|c|c|c|c|}
\hline $\begin{array}{c}\text { Sources } \\
\text { of } \\
\text { variation }\end{array}$ & & $\begin{array}{c}\delta^{13} \mathrm{C} \\
(\%)\end{array}$ & & & $\begin{array}{c}\delta^{15} \mathrm{~N} \\
(\%)\end{array}$ & & & $\begin{array}{c}\delta^{34} \mathrm{~S} \\
(\%)\end{array}$ & \\
\hline & $\mathrm{MS}$ & $\mathrm{F}$ & $\mathrm{p}$ & $\mathrm{MS}$ & $\mathrm{F}$ & $\mathrm{p}$ & $\mathrm{MS}$ & $\mathrm{F}$ & $\mathrm{p}$ \\
\hline Dates & 4.73 & $\mathrm{~F}_{4,20}=7.56$ & $<0.001$ & 4.12 & $\mathrm{~F}_{4,20}=34.50$ & $<0.001$ & 0.57 & $\mathrm{~F}_{4,20}=0.49$ & $\mathrm{NS}$ \\
\hline
\end{tabular}

$(-19.9 \pm 1.2 \%$; mean \pm SD), between -0.5 and $2.7 \%$ o (1.6 $\pm 0.9 \%$; mean $\pm \mathrm{SD})$, and between 15.5 and $19.8 \%$ (17.7 $\pm 1.1 \%$; mean $\pm \mathrm{SD})$, respectively (Fig. 5). One way ANOVA results showed a significant variability according to sampling date for $\delta^{13} \mathrm{C}, \delta^{15} \mathrm{~N}$ but not for $\delta^{34} \mathrm{~S}$ (Table 1). Tukey's Multiple Comparison Test showed that for both delta values there were significant differences between early spring samples (February, March, April) and late spring or summer samples (May, June, July), with a tendency for both delta values to increase over time. The amount of material was not sufficient to perform individual colony isotopic measurements for fall and winter samples.

Using our quantitative data and literature, we have calculated (Table 2) that, during phytoplankton blooms (February-April), a population of E. posidoniae at a depth of $10 \mathrm{~m}$ may filter up to $36 \mathrm{~L}$ of water per day and per $\mathrm{m}^{2}$ of seafloor, corresponding to a transfer of 0.3 and $1.3 \mathrm{mg} \mathrm{DM}$ of nitrogen and carbon, respectively.

\section{DISCUSSION}

Our results show the important contribution of $E$. posidoniae to the epiphytic biomass of $P$. oceanica. It is an early colonizer of the leaf surface, developing before the characteristic photophilous algae, and therefore it contributes mostly to spring epiphyte biomass. Epiphytic accrual on $P$. oceanica is progressive and involves a succession of organisms from a bacterial biofilm to a complex multi-layered epiphytic community
(NovaK, 1984; MAZZElla \& Russo, 1989; CEBRIAN et al., 1999). E. posidoniae develops before photophilous macroalgae and faster than calcareous algae (LEPOINT et al., 2007). This successional pattern is common at the NW Mediterranean basin scale (VAN DER BEN, 1971; MAZZELLA \& RUSSO, 1989; DALla Via et al., 1998; CEBRIAN et al., 1999; PRADO et al., 2008; JACQUEMART \& DEMOULIN, 2008) and implies that common environmental factors govern the epiphytic temporal settlement.

There is an important gap between leaf fall (September) and recolonization of leaves of $P$. oceanica (from January but mainly at the end of winter) by larvae of $E$. posidoniae. For many epiphytic bryozoans, other habitats (i.e. rhizomes, rocks and stones) may have overwintering populations that contribute to supplying larvae in spring for leaf colonization (COCITO et al., 2012, LEPOINT et al., 2014). This is not the case for E. posidoniae as this species is strictly only found on leaves of P. oceanica (GAUTIER, 1961; MATRICARDI et al., 1991). Connectivity between populations growing at different depths in the meadow and affected by differences in the phenology of the host plant (e.g. temporal difference of leaf growth and fall between deeper and shallower beds) may be important to ensure the supply of recruits between different meadow areas. Nevertheless, a time gap exists between leaf fall and recolonization peak in March. Therefore it is probably crucial that this species (similarly to other Electra species) has planktonotrophic larvae able to survive a longer time in the water column in comparison to most 

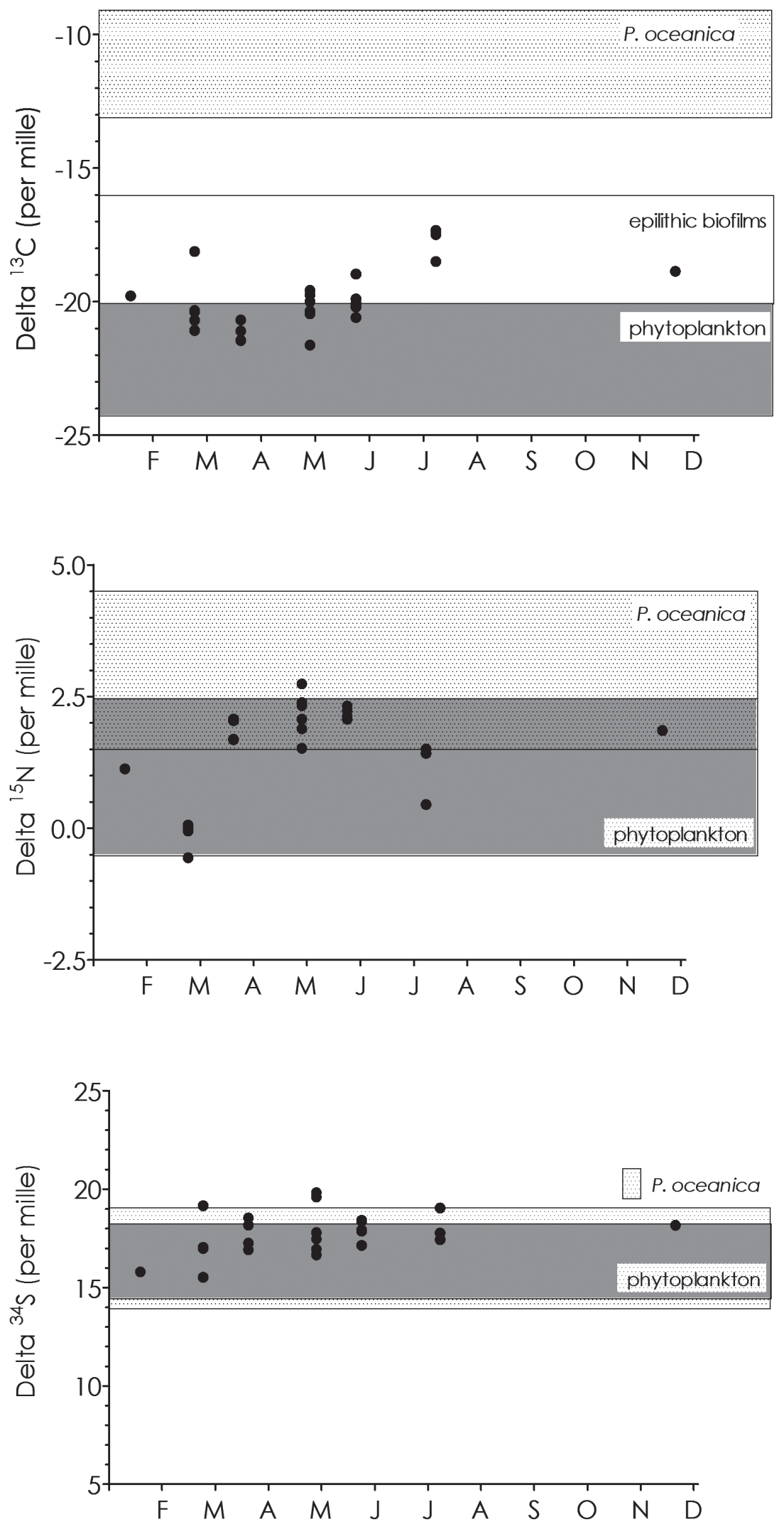

Fig. 5. $-\delta^{13} \mathrm{C}, \delta^{15} \mathrm{~N}$ and $\delta^{34} \mathrm{~S}$ values (mean \pm s.d.) of colonies of Electra posidoniae settled on leaves of Posidonia oceanica collected at a depth of $10 \mathrm{~m}$ in the Revellata Bay between February 2003 and December 2004. Range for phytoplankton and for $P$. oceanica from LEPOINT et al. (2000) and LEPOINT et al. (2003). Range for biofilm grown on artificial substrates from VERMEULEN (2012). 


\section{TABLE 2}

Surface covering, biomass, filtered volume and daily planktonic biomass filtered by Electra posidoniae Gautier in a Posidonia oceanica meadow (Revellata Bay, Corsica). Data used for calculation come from a: this study; b: (Lepoint et al., 2004); c: (Lisbjerg \& Petersen, 2000). See Material and Method for details.

\begin{tabular}{|c|c|c|c|c|c|c|c|c|c|}
\hline \multirow[t]{2}{*}{$\begin{array}{l}\stackrel{\tilde{J}}{\tilde{\pi}} \\
0\end{array}$} & \multicolumn{2}{|c|}{ 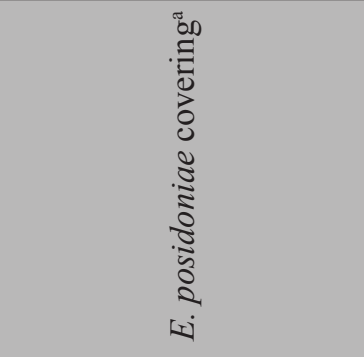 } & \multicolumn{2}{|c|}{ 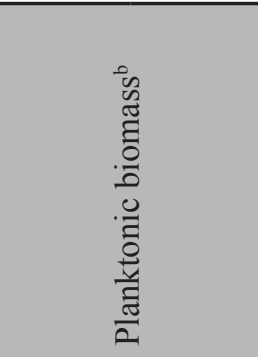 } & \multirow[t]{2}{*}{ 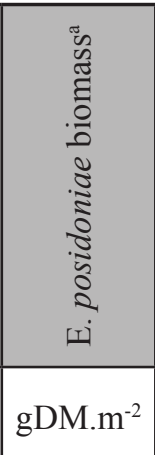 } & \multirow{2}{*}{ 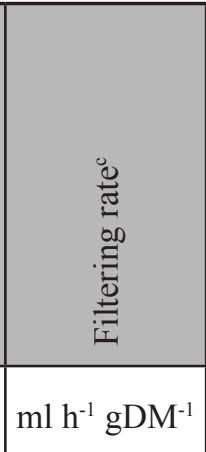 } & \multirow{2}{*}{ 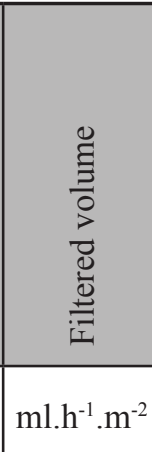 } & \multirow{2}{*}{ 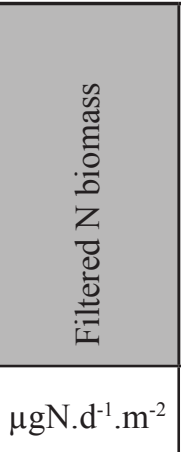 } & \multirow{2}{*}{ 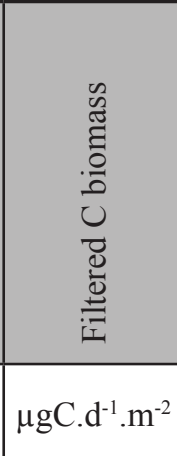 } \\
\hline & $\mathrm{cm}^{2}$ shoot $^{-1}$ & $\mathrm{~cm}^{2} \mathrm{~m}^{-2}$ seafloor & $\mu \mathrm{gN} \mathrm{L}^{-1}$ & $\mu \mathrm{gC} \mathrm{L}^{-1}$ & & & & & \\
\hline January & 1.1 & 507 & 13.2 & 71.4 & 0.9 & 20 & 19 & 1 & 8 \\
\hline February & 32.8 & 14815.1 & 31.9 & 146.4 & 27.3 & 20 & 545 & 104 & 479 \\
\hline March & 83 & 37515.3 & 31.9 & 146.4 & 69 & 20 & 1381 & 264 & 1213 \\
\hline April & 90.6 & 40955.5 & 31.9 & 146.4 & 75.4 & 20 & 1507 & 288 & 1324 \\
\hline May & 84.6 & 38218.1 & 22.7 & 89.5 & 70.3 & 20 & 1406 & 192 & 755 \\
\hline July & 25.7 & 11600 & 22.7 & 89.5 & 21.3 & 20 & 427 & 58 & 229 \\
\hline September & 0.2 & 99.4 & 19.8 & 73.8 & 0.2 & 20 & 4 & $<0.5$ & 2 \\
\hline November & 0.02 & 9.5 & 13.2 & 71.4 & $<0.1$ & 20 & $<1$ & $<0.1$ & $<0.5$ \\
\hline December & 1.2 & 547 & 13.2 & 71.4 & 1 & 20 & 20 & 2 & 9 \\
\hline
\end{tabular}

other bryozoan larvae (GAUTIER, 1961). The life span of such larvae is unknown but is estimated by GAUTIER (1961) to be a few weeks. Larvae of E. posidoniae are potentially major contributors to meroplankton (i.e. the larval planktonic stage of benthic animals) in the water column, considering the maximal colony density found at a depth of $10 \mathrm{~m}$ (i.e. more than 100,000 colonies per $m$ square).

Leaf colonization by E. posidoniae is restricted both spatially and temporally. This restriction is partially due to the larval "choice" to specifically settle on the inner concave side of the leaf (MATRICARDI et al, 1998; this study). Reasons for such specific settlement are unclear (e.g. competition with macroalgae and/or feeding current organization) (MATRICARDI et al, 1998). Competition with macroalgae is often invoked to explain the spatio-temporal restriction of animal settlement and to explain their seasonal eviction from certain benthic habitats, as it is the case for epiphytic communities (MAZZELLA \& RUSSO, 1989; DALla VIA et al., 1998; PRADO et al., 2008). In addition to competition, a colony of $E$. posidoniae may be overgrown by macroalgae. This has been observed on the apex of $P$. oceanica leaves where many photophilous brown macroalgae grow, particularly in late spring and summer (see fig. in MAZzELLA et al., 1992).

Nevertheless, middle parts of the leaves of $P$. oceanica are rarely or never colonised by photophilous macroalgae and show the maximum of colonisation by E. posidoniae. Therefore, the decreasing biomass of colonies of E. posidoniae almost to the point of disappearance before leaf abscission is not solely related to spatial competition or algae overgrowth. Trophic constraints could also explain this observed pattern. Indeed, the peak of colonisation by Electra and its biomass increase clearly match the phytoplanktonic dynamic, and particularly 
the diatom bloom in the Revellata bay (LEPOINT et al., 2004). Many Mediterranean benthic suspensivores experience a drastic decrease in their activity or biomass in late spring and summer (i.e. aestivation) as a consequence of food shortage (COMA \& RIBES, 2003). Diatoms, a major contributor to small suspensivore feeding, are abundant in the water column only during late winter and early spring (February to March, sometimes April). When their biomasse decreases, phytoplanktonic communities become dominated by smaller organisms (2 - 20 $\mu \mathrm{m})$, which are probably consumed less by large bryozoans (MCKINNEY \& JACKSON 1989). Food shortage may occur in this system for benthic suspensivores such as gorgonian corals and is a major cause of mortality for many species (COMA $\&$ RiBES, 2003). Food shortage could thus be likely to affect survival of $E$. posidoniae after the phytoplanktonic bloom, even in the absence of competition with epiphytic macroalgae.

Nevertheless, alternative food sources exist in the seagrass meadow, for example re-suspended particles coming from dead seagrass material as well as detached epiphytic microalgae (i.e. tychoplankton). The latter are very abundant on seagrass leaves as epiphytes (NOVAK, 1984; MAZZELla \& RusSo, 1989; DE STEFANO et al., 2000) and may detach because of leaf movements. There is no doubt, considering the isotopic data, that E. posidoniae relies heavily on phytoplanktonic biomass for feeding. However, phytoplankton is unlikely to represent their exclusive food source. Indeed, their $\delta^{13} \mathrm{C}$ values were always in the upper part of the range of planktonic $\delta^{13} \mathrm{C}$ values, and close to $\delta^{13} \mathrm{C}$ values of epilithic biofilm. They were also higher than those of suspensivore organisms found in other habitats (e.g. rocky habitats) (LEPOINT et al., 2000). A significant contribution from alternative food source(s) displaying a higher $\delta^{13} \mathrm{C}$ value cannot be excluded, particularly during the late spring and the summer, when phytoplanktonic biomass is low. Considering the isotopic composition ranges displayed by epiphytes and seagrasses, contribution by detached epiphytic diatoms to the diet of E. posidoniae is likely to be more important than the contribution by detritic seagrass material. Contribution of seagrass material to the bryozoan diet was not clearly detected here; but, mathematically, a small contribution cannot be excluded. Additionally, a contribution by microbes associated with detritus and displaying the same isotopic composition to their substrate is also feasible. This is particularly possible in July when bryozoan $\delta^{13} \mathrm{C}$ reaches its peak and moves closest to the seagrass isotopic composition. Detritic seagrass may constitute a variable part of the diet of grazers associated with seagrass litter accumulation (STURARO et al., 2010) or seagrass meadows (VIZZINI, 2009; Michel, 2011). Detritic particles found in the meadow ranged widely in terms of size, as dead leaves may be fragmented inside the meadow by water motion (i.e. hydrophysical fragmentation), by microbial degradation, and by detrivorous fauna producing large amounts of fecal pellets. This material may be re-suspended and thereby become available for bryozoan feeding. Due to the colony size we were not able to measure stable isotopic composition in fall and early winter samples when detritic seagrass particles are sometimes abundant in the water column (DAUBY et al., 1995).

In our study, data relating to the stable isotopes composition of nitrogen and sulphur did not prove particularly useful as they did not discriminate very well between the potential food sources. However, $\delta^{15} \mathrm{~N}$ values confirmed the low trophic level of E. posidoniae (i.e. close to primary producer isotopic compositions and lower than those of zooplankton, LEPOINT et al. 2000) and, therefore, the low contribution of zooplankton (i.e. primary consumers) as a potential food source.

It is well established that meadows of $P$. oceanica function as a trap for planktonic particles (GACIA et al., 2002). Suspensivore activity, including that of E. posidoniae, is another possible mode of transfer between the water column and benthic compartment, increasing the role of the meadow as a sink for water column primary production (LEMMENS 
et al., 1996). Such coupling is significant in Australian seagrass meadows, although mainly attributed to macrobenthic suspensivores (LEMMENS et al., 1996). In March and April 2003 (i.e. during phytoplankton bloom), the calculated surface area of E. posidoniae reached $4 \mathrm{~m}^{2}$ of colony per $\mathrm{m}^{2}$ of seafloor (Table 2). Based on published measurements for bryozoan filtering capacities (LISBJERG \& PETERSEN, 2000), and on phytoplanktonic biomasses measured in our study area (LEPOINT et al., 2004), phytoplanktonic biomass potentially trapped by the feeding activity of E. posidoniae and transferred from the water column to the benthic compartment was estimated (Table 2). Filtered volume and biomass transfer are a small fraction of the particles settling in the meadow (GACIA et al., 2002), but this fraction is concentrated in the epiphytic compartment and is enriched in nitrogen and phosphorus, two elements that often limit primary production and that may indirectly benefit $P$. oceanica and other epiphytes through the waste products of E. posidoniae $\left(\mathrm{NH}_{4}\right.$ for example) (BRACKEN, 2004).

In conclusion, it appears that E. posidoniae is a central species of the leaf epiphytic community on $P$. oceanica, dominating the epiphytic biomass in early spring. It contributes to the coupling between the water column and the seagrass meadow and is likely to significantly contribute to the planktonic larval community. Its spatio-temporal colonization pattern may be related to competition with other epiphytes, and probably to food shortages occurring in late spring and summer. It is mainly a phytoplankton feeder; although alternative food sources cannot be excluded (tychoplankton and detritus of $P$. oceanica).

Many questions relating to this epiphytic specialist remain unanswered, such as the driver of larval specific positioning, its reproductive strategy to fill the gap between leaf fall and leaf growing season, or the way it interacts with its vegetal host (adhesion, positive/negative interactions) or with other epiphytes.

\section{ACKNOWLEDGEMENTS}

Authors are grateful to STARESO for their support and for access to laboratory facilities. Many thanks to Loïc Michel for his critical corrections of this manuscript and to François Remy for SEM photography of Electra posidoniae. G.L. is presently Research Associate at Fonds National de la Recherche Scientifique (F.R.S.- FNRS)(BELGIUM), and benefited from a postdoctoral fellowship from FRS - F.N.R.S during this study. This study was financed by a FRS - F.N.R.S contract (FRFC 2.45.69.03) and the Action de Recherche Concertée 10/533 (French-speaking Community of Belgium). This is the MARE paper number 269.

\section{REFERENCES}

Alcoverro T, Perez M \& Romero J (2004). Importance of within-shoot epiphyte distribution for the carbon budget of seagrasses: the example of Posidonia oceanica. Botanica Marina, 47: 307312.

Balata D, Piazzi L, Nesti U, Bulleri F \& BERTOCCI I (2010). Effects of enhanced loads of nutrients on epiphytes on leaves and rhizomes of Posidonia oceanica. Journal of Sea Research, 63: 173-179.

Boero F, Chessa L, Chimenz C \& Fresi E (1985). The zonation of epiphytic hydroids on the leaves of some Posidonia oceanica (L.) Delile beds in the central Mediterranean. Pubblicazione della Stazione Zoologica di Napoli I : Marine Ecology, 6: 27-33.

BOROWITZKA MA, LAVERY PS \& VAN KEULEN M (2006). Epiphytes of seagrasses. In: LARKUM AWD, OrTh RJ, DuARTE CM (eds). Seagrasses: Biology, Ecology and Conservation, Springer, Berlin: 441-461.

BRACKEN M (2004). Invertebrate-mediated nutrient loading increases growth of an intertidal macroalga. Journal of Phycology, 40: 1032-1041.

Cebrian J \& Lartigue J (2004). Patterns of herbivory and decomposition in aquatic and terrestrial ecosystems. Ecological Monographs, 74: $237-259$

Cebrian J, Enriquez S, Fortes M, Agawin N, VERMAat JE, DUARTE CM (1999). Epiphyte 
accrual on Posidonia oceanica (L.) Delile leaves: implications for light absorption. Botanica Marina, 42: 123-128.

Cocito S, Lombardi C, Ciuffardi F \& GAmbi MC (2012). Colonization of Bryozoa on seagrass Posidonia oceanica 'mimics': Biodiversity and recruitment pattern over time. Marine Biodiversity, 42: 189-201.

COMA R \& RiBes M (2003). Seasonal energetic constraints in Mediterranean benthic suspension feeders: effects at different levels of ecological organization. Oikos, 101: 205-215.

CONNOLly RM \& SCHLACHER TA (2013). Sample acidification significantly alters stable isotope ratios of sulfur in aquatic plants and animals. Marine Ecology Progress Series, 493: 1-8.

Dalla Via J, Sturmbauer C, Schonweger G, Sotz E, MATHEKowitsch S, STIFTER M, RIEGER R (1998). Light gradients and meadow structure in Posidonia oceanica: ecomorphological and functional correlates. Marine Ecology Progress Series, 163: 267-278.

Dauby P, Bale AJ, Bloomer N, Canon C, Ling RD, Norro A, Robertson JE, Simon A, ThÉATE J-M, WATSON AJ, FANKignoulle M (1995). Particle fluxes over a Mediterranean seagrass bed: a one year case study. Marine Ecology Progress Series, 126: 233-246.

De Stefano M, Marino D \& Mazzella L (2000). Marine taxa of i on leaves of Posidonia oceanica, including a new species and two new varieties. European Journal of Phycology, 35: 225-242.

Gacia E, Duarte CM \& Middelburg JJ (2002). Carbon and nutrient deposition in a Mediterranean seagrass (Posidonia oceanica) meadow. Limnology and Oceanography, 47: 23-32.

Gacia E, Costalago D, Prado P, Piorno D \& TOMAS F (2009). Mesograzers in Posidonia oceanica meadows: an update of data on gastropodepiphyte-seagrass interactions. Botanica Marina, 52: 439-447.

GAUTIER YV (1961). Recherches écologiques sur les bryozoaires Chilostomes en Méditerrannée occidentale. Thèse de Doctorat, Université de Marseille, Marseille.

HAYWARD PJ (1975). Observations on the bryozoan epiphytes of Posidonia oceanica from the island of Chios (Aegean Sea). In: Pouyet S (ed), Bryozoa, Presse de l'Université Claude Bernard, Lyon: 347-356.
JACQUEMART J \& DEMOULIN V (2008). Comparison of the epiphytic macroflora of Posidonia oceanica leaves in different meadows of the western Mediterranean. Flora Mediterranea, 18: 393-420.

LEMMENS JWTJ, Clapin G, LAVERY PS \& CARY J (1996). Filtering capacity of seagrass meadows and other habitats of Cockburn Sound, Western Australia. Marine Ecology Progress Series, 143: 187-200.

Lepoint G, HaVelange S, Gobert $\mathrm{S}$ \& BOUQUEGNEAU JM (1999). Fauna vs flora contribution to the leaf epiphytes biomass in a Posidonia oceanica seagrass bed (Revellata Bay, Corsica). Hydrobiologia, 394: 63-67.

Lepoint G, Nyssen F, Gobert S, Dauby P \& BOUQUEGNEAU JM (2000). Relative impact of a seagrass bed and its adjacent epilithic algal community in consumer diets. Marine Biology, 136: 513-518.

LePoint G, Dauby P, Fontaine M, BouQuegneau JM \& GOBERT S (2003). Carbon and nitrogen isotopic ratios of the seagrass Posidonia oceanica: Depth-related variations. Botanica Marina, 46: 555-561.

LEPoINT G, Gobert S, DAUBy P \& BOUQUEGNEAU JM(2004). Contributions of benthic and planktonic primary producers to nitrate and ammonium uptake fluxes in a nutrient-poor shallow coastal area (Corsica, NW Mediterranean). Journal of Experimental Marine Biology and Ecology, 302: 107-122.

LEPOINT G, BALANCIER B \& GOBERT S (2014). Seasonal and depth-related biodiversity of leaf epiphytic Cheilostome Bryozoa in a Mediterranean Posidonia oceanica meadow. Cahiers de Biologie Marine, 55: 57-67.

LisbJerg D \& Petersen JK (2000). Clearance capacity of Electra bellula (Bryozoa) in seagrass meadows of Western Australia. Journal of Experimental Marine Biology and Ecology, 244: 285-296.

Mabrouk L, Hamza A, Ben Brahim M \& Bradai MN (2011). Temporal and depth distribution of microepiphytes on Posidonia oceanica (L.) Delile leaves in a meadow off Tunisia. Marine Ecology, 32: 148-161.

Mateo MA, Cebrian J, Dunton K \& Mutchler T (2006). Carbon Flux in Seagrasses. In: LARKUM AWD, ORTH RJ, DuARTE CM (eds). Seagrasses: Biology, Ecology and Conservation, Springer, Berlin:159-192. 
Matricardi G, Montagna P \& Pisano E (1991). Settlement and growth strategies of Electra posidoniae Gautier on Posidonia oceanica (L.) Delile. In: BigeY FP (ed), Bryozoaires actuels et fossiles: Bryozoa living and fossil. Nantes (France): 255-262.

Mazzella L, SCiPione MB \& BUiA MC (1989). Spatio-temporal distribution of Algal and Animal communities in a Posidonia oceanica meadow. Pubblicazione della Stazione Zoologica di Napoli I : Marine Ecology, 10: 107-129.

MAZZELLA L \& RUSSO GF (1989). Grazing effect of two Gibbula species (Mollusca, Archaeogastropoda) on the epiphytic community of Posidonia oceanica leaves. Aquatic Botany, 35: 353-373.

Mazzella L, Buia MC, GAMBI MC, LORENTI M, Russo GF, SCIPIONE MB, ZUPO V (1992). Plantanimal trophic relationships in the Posidonia oceanica ecosystem of the Mediterranean Sea: a review. In: JOHN DM, HAWKINS SJ, PRICE JH (eds), Plant-Animal Interactions in the Marine Benthos, Clarendon Press, Oxford: 165-187.

MCKINNEY FK \& JACKSON JBC (1989). Bryozoan Evolution. Unwin Hyman, Boston.

MicheL L (2011). Multidisciplinary study of trophic diversity and functional role of amphipod crustaceans associated to Posidonia oceanica meadows. PhD Thesis, University of Liège.

NovaK R (1984). A Study in Ultra-Ecology: Microorganisms on the Seagrass Posidonia oceanica (L.) Delile. Pubblicazione de,lla Stazione Zoologica di Napoli I : Marine Ecology 5: 143-190.

Nikulina EA, HANel R \& Schafer P (2007). Cryptic speciation and paraphyly in the cosmopolitan bryozoan Electra pilosa - Impact of the Tethys closing on species evolution. Molecular Phylogenetics and Evolution, 45: 765-776.
PERES J-M \& PiCARD J (1964). Nouveau manuel de bionomie benthique de la mer Méditerranée. Edition revue et augmentée. Publication de la Station Marine d'Endoume, Marseille.

PINNEGAR JK \& POLUNIN NVC (1999). Differential fractionation of $\delta^{13} \mathrm{C}$ and $\delta^{15} \mathrm{~N}$ among fish tissues: implications for the study of trophic interactions. Functional Ecology, 13: 225-231.

Prado P, Alcoverro T \& Romero J (2008). Seasonal response of Posidonia oceanica epiphyte assemblages to nutrient increase. Marine Ecology Progress Series, 359: 89-98.

Sturaro N, Caut S, Gobert S, Bouquegneau J-M \& LEPOINT G (2010). Trophic diversity of idoteids (Crustacea, Isopoda) inhabiting the Posidonia oceanica litter. Marine Biology, 157: 237-247.

TOMAs F, TURon X \& ROMERo J (2005). Effects of herbivores on a Posidonia oceanica seagrass meadow: importance of epiphytes. Marine Ecology Progress Series, 301: 95-107.

VAN Der BEn D (1971). Les épiphytes des feuilles de Posidonia oceanica Delile sur les côtes françaises de la Méditerranée. Mémoires de l'Institut Royal des Sciences Naturelles de Belgique, 168: 1-101.

VERMEULEN S (2012). Spatial and temporal responses of marine gastropods and biofilms to urban wastewater pollution in a Mediterranean coastal area. PhD Thesis, University of Liège.

VIZZINI S (2009). Analysis of the trophic role of Mediterranean seagrasses in marine coastal ecosystems: a review. Botanica Marina, 52: 383393.

Received: January 30th, 2014

Accepted: May 26th, 2014

Branch editor: Tom Artois 